\author{
R. Namitha ${ }^{1}$, Karthik Kannan ${ }^{2}$, D. Radhika ${ }^{1}$, G. Krishnamurthy ${ }^{3}$
}

\title{
Solvothermal / Hydrothermal Manufacturing of Carbon Nanotubes for Hydrogen storage: A Comparative Study
}

\author{
${ }^{1}$ Jain Deemed-to-be University, Jakkasandra post, Ramnagara District, India, namitha19kkp@gmail.com; \\ radhikadv8@gmail.com \\ ${ }^{2}$ Center for Advanced Materials, Qatar University, Doha, Qatar, karthikkannanphotochem@gmail.com \\ ${ }^{3}$ Department of Studies in Chemistry, Bangalore University, Jnanabharathi Campus, Bangalore, India, \\ drgkmurthy.bub@gmail.com
}

\begin{abstract}
Investigation on the manufacturing of multi-walled carbon nanotubes (MWNTs) by solvothermal and hydrothermal procedure and the electrochemical behavior of these nanostructured electrode materials for hydrogen storage has been presented. The physical and morphological properties of prepared carbon nanotubes were studied by X-ray diffraction (XRD), Scanning, and Transmission electron microscopy (SEM and TEM). Furthermore, the electrochemical properties of MWCNTs were revealed by galvanostatic charge-discharge and measurement of cyclic voltammetry and the results revealed that both MWNTs exhibited higher electrochemical capacitance and stable cycling performance. Interestingly, MWNTs synthesized from hydrothermal procedure shows an extreme discharge capacity of $423 \mathrm{mAh} / \mathrm{g}$, concerning hydrogen storage of $~ 1.5 \mathrm{wt} \%$, and MWNTs synthesized from solvothermal procedure shows a capacity of discharge $394.8 \mathrm{mAh} / \mathrm{g}$. corresponds to $\sim 1.4 \mathrm{wt} \%$, was attained reproducibly at $25{ }^{\circ} \mathrm{C}$ for about $100 \mathrm{mg}$ of MWCNTs. This outcome infers that the MWNTs are extremely assuring electrochemical hydrogen storage materials for PEM fuel cells and rechargeable batteries.

Keywords: solvothermal-hydrothermal method; carbon nanotubes; hydrogen storage; rechargeable batteries; electrochemical method.
\end{abstract}

Received 17 Novtmber 2020; Accepted 15 December 2020.

\section{Introduction}

Carbon nanomaterials possess a very extensive range of recognized, proposed, and plentiful features with prospective applications in numerous technologies associated with energy, environment, health, microelectronics, optics, transportation, etc. The past two decades have endorsed the progress of solution-based approaches for the production of nanostructures such as nanorods, nanofibres, nanoplates, microspheres, nanotubes [1-5] and their associations with controllable diameter, contour, and structured difficulty. Multiwalled carbon nanotubes (MWNTs) are manufactured with a diversity of procedures, such as arc discharge, chemical vapor deposition, laser vaporization, and so on. In specific, hydro and Solvothermal methodology, as a customary method has offered numerous common ways for the manufacturing of nanostructured materials. The hydrothermal and solvothermal method is the popular low-temperature synthesis route, with or without the addition of metal catalysts [6, 7]. Many researchers call hydrothermal processing as green processing or green chemistry. The area has a lot of advantages over other conventional processes compared to the vapor deposition process or milling like pollution-free, cost-effectiveness, energy saving, better nucleation control, etc [8]. The similarity of the hydrothermal process and accessibility of carbon precursor materials, without the addition of a catalyst, advantageously prefer the new method for the synthesis. The hydrothermal process involves a carbon precursor added with compressed water at high temperature, admits the speed growth of crystalline materials in an environmentally friendly method while altering the particle diameter and morphology by changing pressure, temperature, and time $[9,10]$. Hence hydrothermal methodology has become an important 
method for producing carbon materials.

The solvothermal method has also been provided with several advantages for preparing nanomaterials with controllable size and morphology. The methodology involves the heating of carbon precursor and solvent in the presence of an organic capping agent. It involves three stages, in the first step heating of the solution takes place which results in the dissociation of carbon precursor takes place, in the second step aging of the solution takes place which decides the size of the materials obtained and the third step involves the separation of nanomaterials from solvent. The preparation of multiwalled carbon nanotubes employing a hydrothermal and solvothermal synthesis has been successfully demonstrated for electrochemical hydrogen adsorption studies.

There are many methods for hydrogen adsorption studies like volumetric and gravimetric methods. Out of these methods, the electrochemical method is one of the most advantageous methods for the study of hydrogen adsorption properties. It gives gas storage property as well as electrochemical redox information. There are many researchers attempt to study the hydrogen adsorption of Carbon nanotubes electrochemically. Hydrogen storage by the electrochemical method was done the first time by Nützenadel et al. [11]. They proved the hydrogen storage of $110 \mathrm{mAh} / \mathrm{g}$ which corresponds to $0.39 \mathrm{wt} \%$. Lee et al [12] and Qin et al [13] have also studied hydrogen storage of MWNTs electrochemically. They showed a high discharge capacity of $200 \mathrm{mAh} / \mathrm{g}$. Rajalakshmi et al. [14] arrived with a discharge capacity of $800 \mathrm{mAh} / \mathrm{g}$ corresponds to $2.9 \mathrm{wt} \%$. The cylindrical and hollow structure of Carbon nanotubes offers more active surfaces for the absorption of hydrogen. Physisorption and Chemisorption is the main different mechanisms in which hydrogen interact with nanotubes [15]. Hydrogen storage of CNTs through the electrochemical process involves physisorption. During Physisorption, $\mathrm{H}_{2}$ interacts with nanotube it retains its molecular identity and the aromatic bonding framework is also not altered.

In this study, we report novel hydrothermal and solvothermal methods for the manufacturing of Multiwalled Carbon nanotubes through a common reagent such as Ferrocene as a carbon source. Besides, the hydrogen storage by electrochemical studies is also studied for these materials. The diameter and nanostructures were studied through characterization methods like scanning and transmission electron microscopy (SEM and TEM), Powder X-ray diffraction studies (PXRD), and Raman analysis. We compared here the studies on the electrochemical absorption and desorption of hydrogen in MWNTs produced without metal catalyst addition by a hydrothermal and solvothermal process. The hydrogen capacity was studied for two different types of MWNTs under a normal atmosphere. The relatively high hydrogen adsorption showed by hydrothermally synthesized compared to solvothermal synthesized MWNTs may be due to highly aligned structures of nanotubes.

\section{Experimental}

1.1 Synthesis of multiwall carbon nanotubes by the solvothermal procedure

In a typical synthesis process for the CNTs, Ferrocene (0.5 gm), $\mathrm{NaBH}_{4}(2 \mathrm{gm})$, and dichloroethane $(40 \mathrm{ml})$ were put in a $60 \mathrm{ml}$ autoclave. It was sealed and maintained at $200{ }^{\circ} \mathrm{C}$ for $70 \mathrm{~h}$, then allowed to cool to room temperature. The black color precipitate (raw product) was filtered, washed with dilute $\mathrm{HCl}$ solution, ethanol, and distilled water in sequence. The wet sample was dried in an oven at $60^{\circ} \mathrm{C}$ for $5-6 \mathrm{~h}$.

1.2. Synthesis of multiwall carbon nanotubes by the hydrothermal procedure

Here about $1 \mathrm{~g}$ of Ferrocene dissolved in non-volatile acid aqueous solution. The solution was allowed to stir magnetically by ultrasonication for $30 \mathrm{~min}$ and then taken into a stainless steel autoclave. The autoclave was sealed and placed in a muffle furnace and heated to $200{ }^{\circ} \mathrm{C}$ for $60 \mathrm{~h}$ and allowed to cool to room temperature. The obtained product was filtered and washed several times sequentially with anhydrous ethanol, hydrochloric acid, and deionized water followed by drying in an oven at $100^{\circ} \mathrm{C}$ for $10 \mathrm{~h}$.

The ultimate black products obtained by both the routes were characterized by various analytical techniques like PXRD, FTIR, Raman analysis, SEM, and TEM methods.

\subsection{Characterization}

The obtained MWCNTs were examined by the X-ray diffraction (XRD) studies. The Raman spectral analysis was made using Perkin Elmer, Fourier Transform Raman instruments to get information on the formation of graphite. The structure and morphology of the samples were studied by Scanning and Transmission electron microscope (TEM). The hydrogen storage measurements by the electrochemical method were carried out using an EG and $G$ Potentiostat-Galvanostat $\mu$ Autolab with a PGSTAT30 instrument with GPES software.

\section{Results and Discussions}

\subsection{Structural analysis}

The purity and structure of the synthesized products were analyzed by powder X-ray diffraction (PXRD) Fig. 1 shows the PXRD patterns of the MWNTs. Pattern (a) and (b) correspond to the multiwalled carbon nanotubes synthesized by solvothermal MWCNTs (ST) and hydrothermal MWCNTs (HT) routes. A scanning rate of $0.02^{\circ} \mathrm{s}^{-1}$ has been utilized to record the pattern in the range $10-80^{\circ}$. Both the patterns show a similar type of graphs with two medium intensity peaks at $\sim 26^{\circ}$ and $\sim 42^{\circ}$ indexed to the (002) and (100) graphite planes respectively. The (002) peak arises due to the interlayer assembling of graphene sheets. Sharp peaks indicate the high crystallinity of the product in both the samples. Here we observed the difference in the intensities of the peaks in both the patterns. More intense peaks in the pattern (a) are giving an idea of the higher crystallinity of MWCNTs synthesized by the solvothermal route. No 


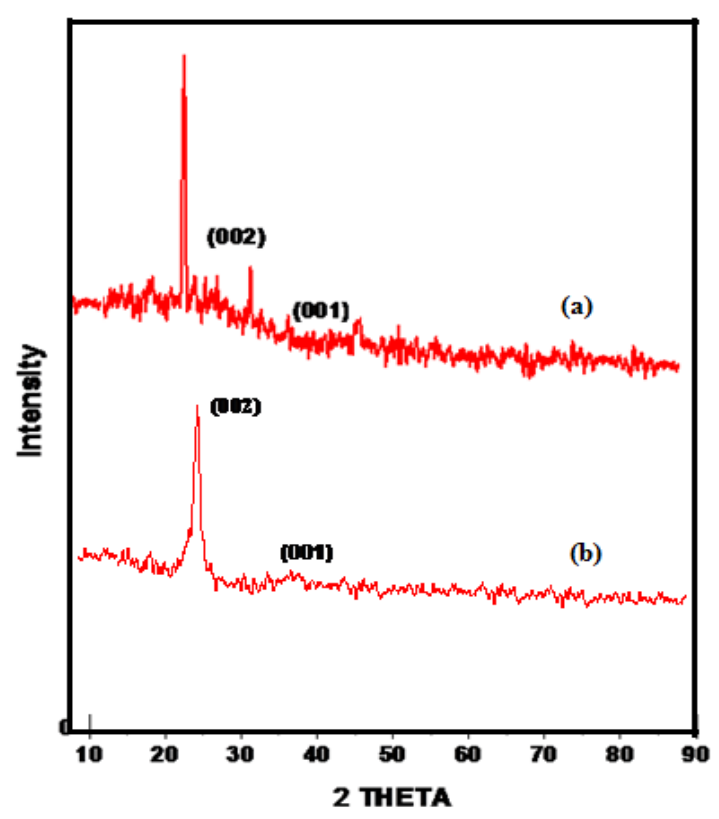

Fig. 1. XRD patterns of as synthesized MWNTs. Pattern (a) corresponds to MWCNTs (ST) and (b) to MWCNTs (HT).

other impurities had been observed in both the patterns. The results show no much difference from the pattern of diffraction of normal MWCNTs [16].

\subsection{Raman studies}

To examine the crystallinity of the MWCNTs synthesized by both the routes, products were further analyzed by Raman spectroscopy. Typical Raman spectrums of the products are shown in Figure 2 . Spectrums (a) and (b) correspond to the samples synthesized by solvothermal and hydrothermal routes, exhibits two main typical graphite bands at $\sim 1548.2 \mathrm{~cm}^{-1}$ and $\sim 1342 \mathrm{~cm}^{-1}$ ( $\mathrm{G}$ and $\mathrm{D}$ band respectively). The G-band was assigned to the Raman-allowed optical mode $\mathrm{E}_{2 \mathrm{~g}}$, which is similar to the carbon atoms $\left(\mathrm{sp}^{2}\right)$ in graphite. The D-band corresponds to the vibrations of carbon atoms in the planar terminations of graphite [17]. RBM band is a characteristic feature of the SWCNTs' Raman spectrum. The presence of RBM in the Raman spectrum of MWCNTs was reported earlier if the diameters of the inner tubes are small enough to be in the order of that of SWCNTs. [18]. The relative intensity ratio between the $\mathrm{D}$ band and $\mathrm{G}$ band is a good indicator of graphitic ordering: the higher the ratio, the higher the disorder degree of graphite. The ratio of intensities of D and G-band $\left(I_{\mathrm{D}} / I_{\mathrm{G}}\right)$ is 0.791 and 0.85 for MWCNTs (ST) and MWCNTs (HT) respectively, an indication of low graphitic nature in both cases.

\subsection{Morphological analysis}

The morphologies of MWCNTs (ST) and MWCNTs (HT) are compared via SEM and TEM measurement and the images are shown in Fig. 3 and Fig 4 respectively. Fig. 3 ( $a$ and $b$ ) for sample synthesized solvothermal, it can be seen that product consists of a large amount of MWCNTs and appear like bamboo sticks. We can see

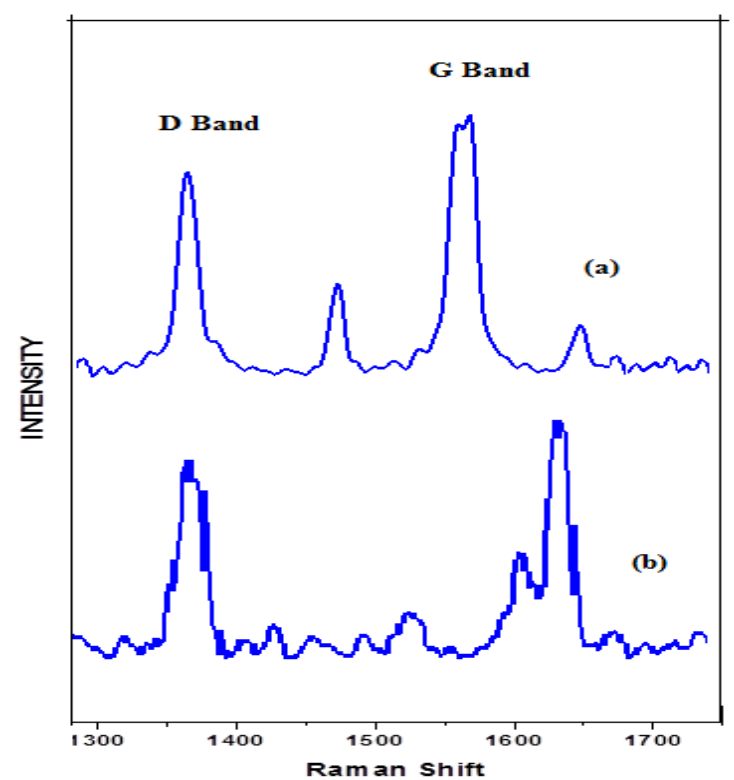

Fig. 2. Raman Spectrum of as synthesized MWNTs. Pattern (a) corresponds to MWCNTs (ST) and (b) to MWCNTs (HT).

that a lot of carbon nanotubes accumulate together and give bamboo sticks like appearance. A close investigation of the CNTs shows that most of the CNTs are having closed ends with a large diameter. On the other hand, Figure 3 (c and d) for hydrothermally synthesized sample shows the formation of well-aligned carbon nanotubes bundles relatively in low yield. A more detailed investigation of solvothermal synthesized products by TEM (Fig. 4 (a) and (b)) reveals that carbon nanotubes have a bamboo-shaped structure with a diameter of about $340-460 \mathrm{~nm}$, while that for the hydrothermally synthesized MWCNTs (Fig. 4 (c) and (d)) indicate that these CNTs are the long and straight mat of ropes with $50-60 \mathrm{~nm}$ in diameter. Fig 4 (c) and (d) also show the presence of catalyst particles deposition at the walls of the tubes which is completely absent in the case of MWCNTs (ST). Hence the product utilized for the electrochemical characterizations appears in SEM and TEM images are with different morphologies and diameters range. Such huge differences in morphology, structure, and diameters between these two types of carbon nanotubes must result in different electrochemical performance when they are used as a working electrode in a three-electrode system. Though SEM and TEM results, the proportion of MWCNTs (ST) and MWCNTs (HT) were estimated to be $\sim 90 \%$ and $\sim 65-70 \%$ among the products.

\subsection{Electrochemical studies}

\subsubsection{Electrode preparation}

For the hydrogen studies of synthesized carbon nanotubes, the electrodes prepared by grinding $1: 3$ ratio of MWCNTs $(10 \mathrm{mg})$ with $\mathrm{Cu}$ powder respectively along with a binder polytetrafluoroethylene (PTFE). The mixture was ground mechanically on a $\mathrm{Ni}$ mesh in continuation with heating at $200^{\circ} \mathrm{C}$ for $1 \mathrm{~h}$. The electrode 

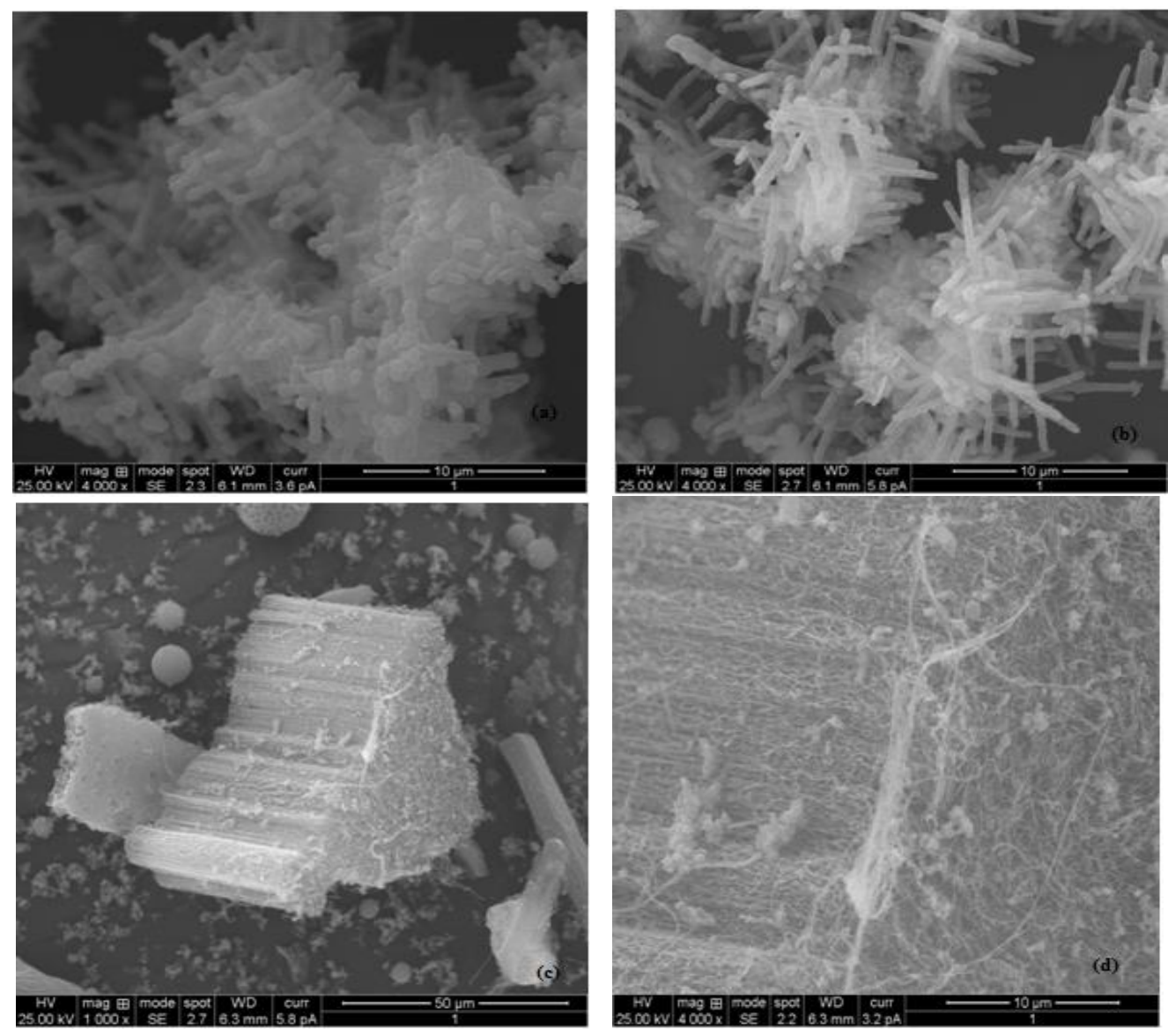

Fig. 3.: SEM images for as synthesized samples. Images (a) and (b) corresponds to MWCNTs (ST) and images (c) and (d) corresponds to MWCNTs (HT).
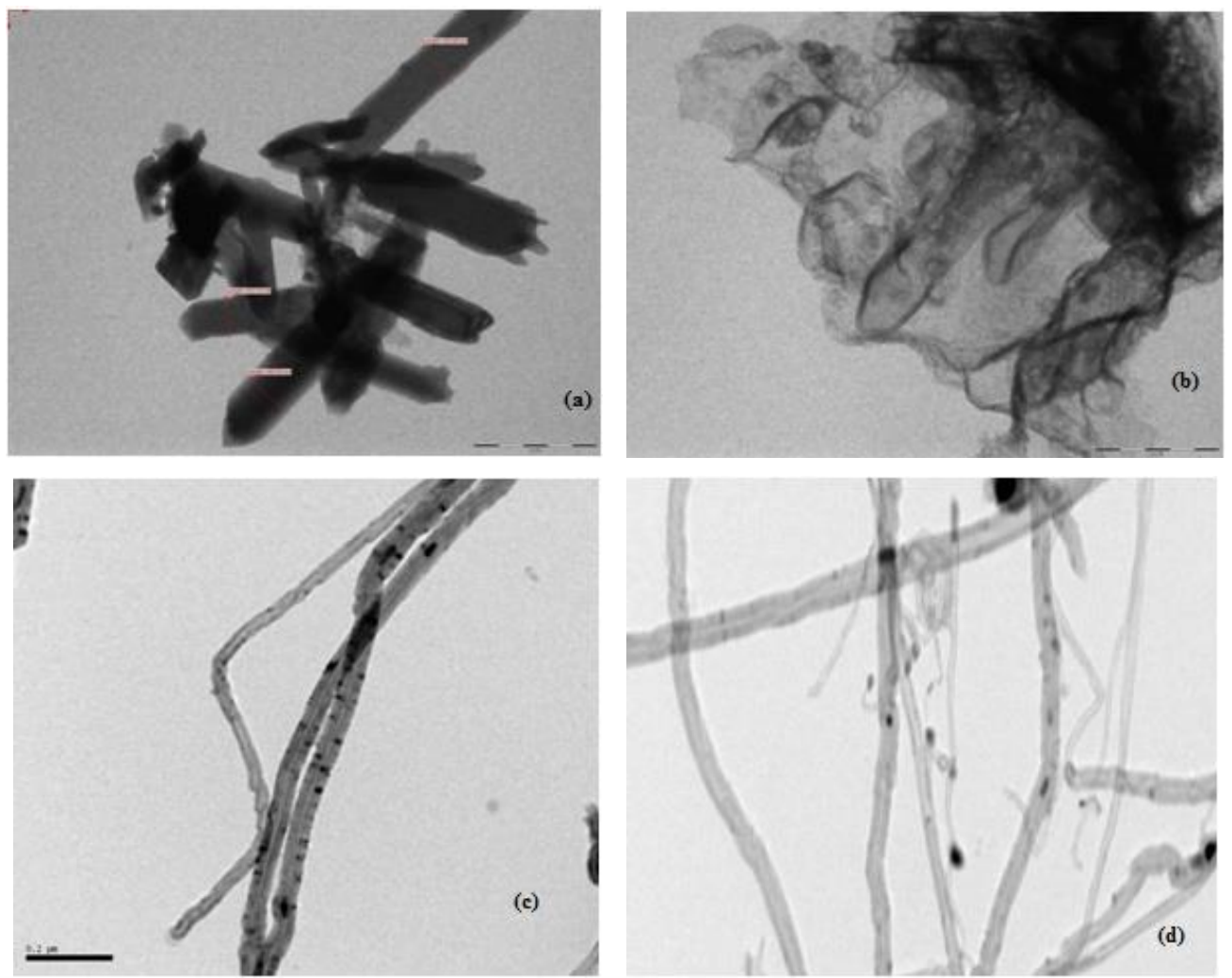

Fig. 4. TEM images for as synthesized samples. Images (a) and (b) corresponds to MWCNTs (ST) and images (c) and (d) corresponds to MWCNTs (HT). 
geometrical area was about $2 \mathrm{~cm}^{2}$.

2.4.2 Hydrogen storage of carbon nanotubes by electrochemical measurement

The hydrogen storage of capacity of the MWCNTs synthesized by two different routes was determined by using electrochemical measurements by using an EG and $\mathrm{G}$ Potentiostat-Galvanostat. The three electrodes set up in an open-cell consist of the working electrode as MWCNTs electrodes, Platinum as a counter electrode, and saturated calomel as reference electrode along with $6 \mathrm{M} \mathrm{KOH}$ as the electrolyte solution. To gather electrochemical data we used Chronopotentiometry, controlled potential coulometry, and cyclic voltammetry measurements. For the activation of electrodes, Cyclic Voltammetry measurements for the MWCNTs electrodes were employed in a range of potential values between -1 to $+0.5 \mathrm{~V}$ with a scan rate of $100 \mathrm{mVs}^{-1}$ in normal pressure and temperature. The electrochemical chargedischarge capacity of sample electrodes was measured in galvanostat under different current loads ranging from $10 \mathrm{~mA}$ to $100 \mathrm{~mA}$ of MWCNTs during charging and discharging. The water in the electrolyte dissociates at the working electrode (CNT) into the adsorbed atomic

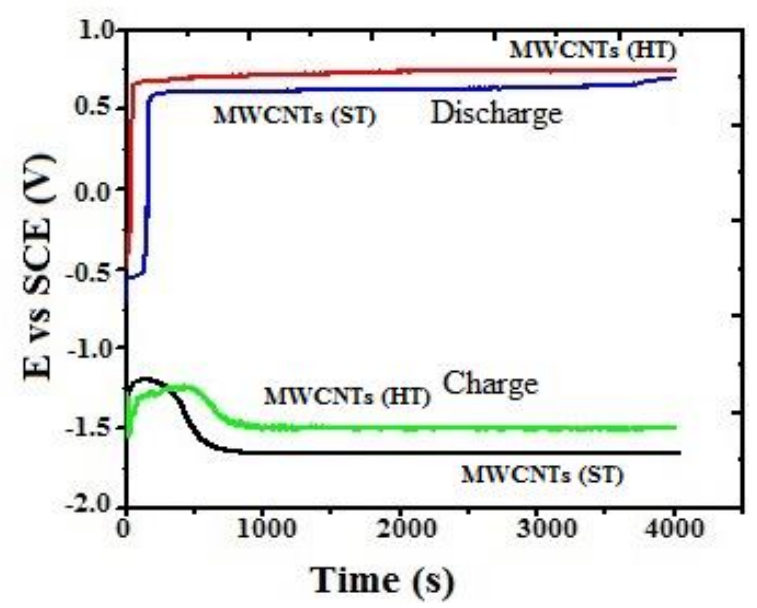

Fig. 5. Charge -discharge of the MWCNTs electrode at $40 \mathrm{~mA}$ current.

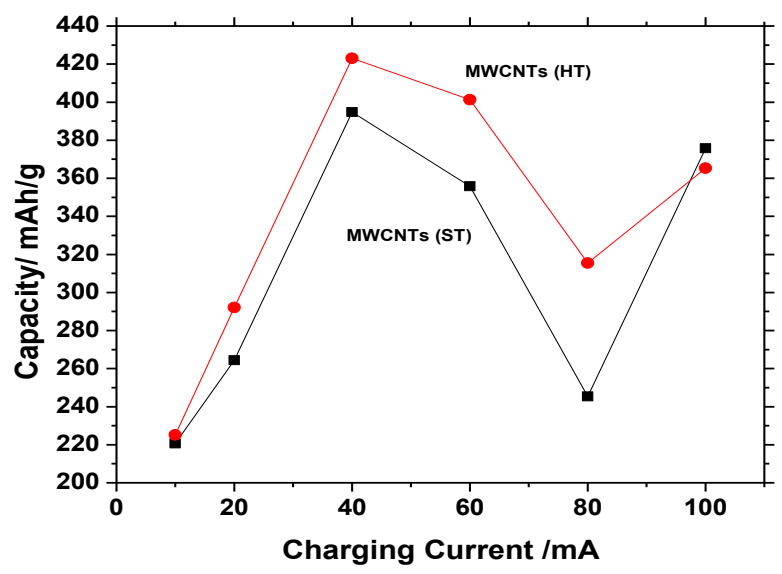

Fig. 6. Electrochemical hydrogen storage capacity of MWCNTs electrodes with respect to the charging current.

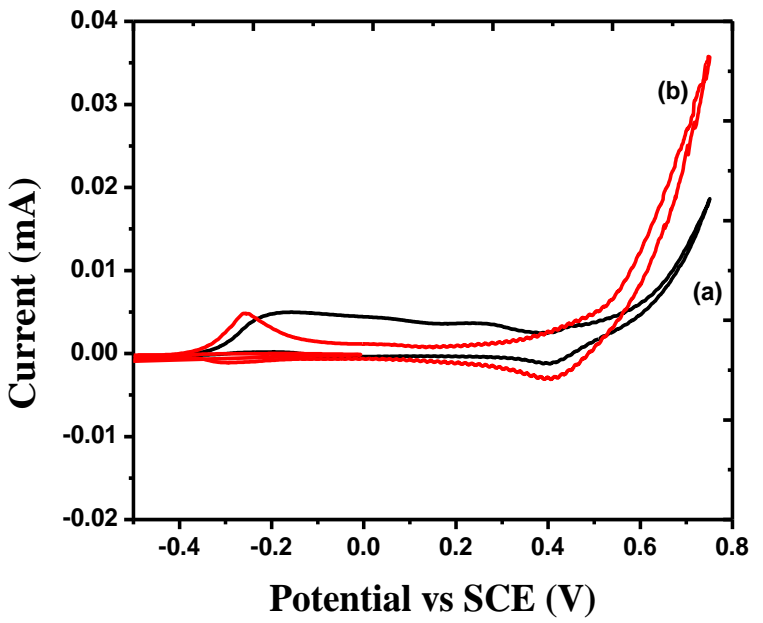

Fig. 7. Cyclic voltammograms (CV): (a) corresponds to the CV for MWCNTs (ST) and (b) CV for MWCNTs (HT).

hydrogen and $\mathrm{OH}^{-}$ions leftover in the electrolyte during the charging of the electrode. The hydrogen in the electrode reacts with the $\mathrm{OH}^{-}$ions in the electrolyte to form water molecules during the discharge process [1922]. This reaction is escorted with a charge transfer hence the quantity of desorbed hydrogen from the electrode can be calculated by measuring the electric charge, which is equal to the product of current and time in a galvanostatic setup. The typical charge and discharge curve at a constant current of $40 \mathrm{~mA}(0.04 \mathrm{~mA})$ for the as-produced MWCNTs are displayed in Figure 5. The potential value of charging and discharging was -0.8 and $-0.6 \mathrm{~V}$ versus standard calomel electrode, respectively for both the electrodes. Charge and discharge capacity achieved by MWCNTs (ST) electrode and MWCNTs (HT) electrode are $394.8 \mathrm{mAhg}^{-1}$ and $423 \mathrm{mAhg}^{-1}$ correspondings to $\sim 1.4 \mathrm{wt} \%$ and $\sim 1.5 \mathrm{wt} \%$ of stored hydrogen. The variation in the charging capacity concerning the charging current (range 10 - $100 \mathrm{~mA}$ ) was found as shown in Figure 6. We had observed maximum charging capacity for the sample electrodes at $40 \mathrm{~mA}$ constant current $394.8 \mathrm{mAhg}^{-1}$ and $423 \mathrm{mAhg}^{-1}$ for the MWCNTs (ST) and MWCNTs (HT) electrodes respectively [23-25]. We can conclude that the samples investigated by other research groups contained only a few percentages of carbon nanotubes, resulting in an electrochemical capacity of 0.39 to $0.9 \mathrm{wt} \%$, but the samples investigated by us contain $90 \%$ of MWNTs giving a higher capacity of $\sim 1.4-1.5 \mathrm{wt} \%$.

Cyclic Voltammogram (CV) is extensively used to determine the electrochemical process. Figure 7 (a \& b) shows the $\mathrm{CV}$ of the sample electrodes in the -0.75 to $0.75 \mathrm{~V}$ range, after one cycle representing the adsorption and desorption peaks of hydrogen, oxidation and reduction peaks of Copper. Calculation from curves in Fig. 7 (a \& b) showed that the cathodic peak current of hydrogen adsorption and the anodic peak current of hydrogen oxidation were proportional to the sweep rate. This proved that the hydrogen adsorption and hydrogen oxidation controlled the whole reaction [26-28]. 


\section{Conclusion}

In this work, we had made a comparative study for the synthesis of two different types of MWCNTs with the same carbon source via two different synthesis routes. Both kinds of MWCNTs are different in morphologies, length and diameters. The well aligned, straight carbon nanotubes bundles synthesized by hydrothermal routes are with diameter in range of $50-60 \mathrm{~nm}$ and length in micrometers. On the other hand bamboo shaped carbon nanotubes synthesized by solvothermal route are having larger diameter range (340 - $460 \mathrm{~nm})$. Both type of CNTs shown difference in \% yield also. In accordance with SEM and TEM observations bamboo shaped CNTs shown relatively higher $\%$ of production yield $(90 \%)$ than that of straight CNTs $(65-70 \%)$. The electrochemical measurements of two types of carbon nanotubes, MWCNTs (ST) and MWCNTs (HT) as working electrode were systemically determined. It result shows that the charge -discharge capacity of MWCNTs (ST) electrode $394.8 \mathrm{mAh} / \mathrm{g}^{-1}$ ( 1.4 wt \% of hydrogen stored), with a little difference from that MWCNTs (HT) electrodes $\left(423 \mathrm{mAh} / \mathrm{g}^{-1}\right.$ corresponds to $\sim 1.5 \mathrm{wt} \%$ of stored hydrogen).

\section{Acknowledgment}

The Authors like to acknowledge for XRD facility at our Department of Chemistry, Bangalore University. The authors would also extend their acknowledgement to AICTE for SEM facility at UVCE, Bangalore, Indian Institute of Science, Bangalore for Raman spectral studies and IIT Bombay for TEM analysis.

Namitha R. - PhD in Chemistry, Assistant professor of the Chemistry Department;

Karthik Kannan - PhD in Physics, Researcher;

Radhika D. - PhD in Chemistry, Assistant professor of the Chemistry Department;

Krishnamurthy G.- PhD in Chemistry, Professor of the Chemistry Department.

[1] H. Yu, Q. Zhang, J.B. Joo, N. Li, G.D. Moon, S. Tao, L. Wang and Y. Yin, J Mater Chem A 1(39), 12198 (2013). https://doi.org/10.1039/C3TA12722B.

[2] X.-Q. Zhang, Q. Sun, W. Dong, D. Li, A.-H. Lu, J.-Q. Mu and W.-C. Li, J Mater Chem A. 1(33), 9449 (2013). https://doi.org/10.1039/C3TA10660H.

[3] Y.S. Yun, S.Y. Cho, J. Shim, B.H. Kim, S.-J. Chang, S.J. Baek, Y.S. Huh, Y. Tak, Y.W. Park, S. Park and H.-J. Jin, Adv Mat. 25(14), 1993 (2013). https://doi.org/10.1002/adma.201204692.

[4] Q. Cai, Z.-H. Huang, F. Kang and J.-B. Yang, Carbon 42(4), 775 (2004). https://doi.org/10.1016/j.carbon.2004.01.042.

[5] T.-C. Chen, Adv Funct Mater. 23(40), 5066 (2013). https://doi.org/10.1002/adfm.201300614.

[6] H. Kajiura, A. Nandyala and A. Bezryadin, Carbon 43(6), 1317 (2005). https://arxiv.org/abs/condmat/0505378v1.

[7] G. Krishnamurthy and S. Agarwal, Bull. Korean Chem. Soc. 34(10), $3046 \quad$ (2013). https://doi.org/10.5012/bkcs.2013.34.10.3046.

[8] M. Yoshimura and K. Byrappa, Journal of material Science 43(7), 2085 (2008). https://doi.org/10.1007/s10853-007-1853-X.

[9] T. Adschiri, K. Kanazawa and K. Arai, J. Am. Ceram. Soc. 75(9), 2615 (1992). https://doi.org/10.1111/j.11512916.1992.tb05625.x.

[10] M. Bremholm, J. Becker-Christensen and B.B. Iversen. Adv. Mater. 21(35), 3572 (2009). https://doi.org/10.1002/adma.200803431.

[11] C. Nützenadel, A. Züttel and D. Chartouni, Electrochem Solid-State Lett. 2(1), 30 (1999). https://doi.org/10.1149/1.1390724.

[12] S.M. Lee, K.H. An, Y.H. Lee, G. Scifert and T-Frauenheim, J. Am. Chem. Soc. 123(21), 5059 (2001). https://doi.org/10.1021/ja003751+.

[13] X. Qin, X.P. Gao and H.T. Yuan, Electrochem Solid-State Lett. 3(12), $532 \quad$ (2000). https://doi.org/10.1149/1.1391200.

[14] M.M. Shaijumon, S. Ramaprabhu, Chem. Phy. Lett. 374 (5-6) 513 (2003). https://doi.org/10.1016/S00092614(03)00741-3.

[15] T.C. Dinadayalane, A. Kaczmarek, J. Łukaszewicz and J. Leszczynski, J Phys Chem C. 111(20), 7376 (2007),

[16] Y. Mi, Y. Liu, D. Yuan, J. Zhang and Y. Xiao, Journal of Materials science 40(14), 3635 (2005).

[17] Y. Liu, C. Pan and J. Wang, J. Mater. Sci 39(3) 1091 (2004). https://doi.org/10.1021/jp066469j.

[18] X. Zhao, Y. Ando, L.C. Qin, H. Kataura, Y. Maniwa and R. Saito, Physica B, 323(1-4), 265 (2002).

[19] K. Kannan, M.H. Sliem, A.M. Abdullah, K.K. Sadasivuni, B. Kumar, Catalysts 10, 549 (2020) (https://doi.org/10.3390/catal10050549).

[20] K. Kannan, K.K. Sadasivuni, A.M. Abdullah, B. Kumar, Catalysts 10, 495 (2020) (https://doi.org/10.3390/catal10050495).

[21] Karthik Kannan, D. Radhika, A.S. Nesaraj, Mohammed Wasee Ahmed \& R. Namitha, Materials Research Innovations, 24(7), 414 (2020) (https://doi.org/10.1080/14328917.2019.1706032).

[22] K. Pradeeswari, A. Venkatesan, P. Pandi, K. Guru Prasad, K. Karthik, T. Maiyalagan, R. Mohan Kumar, Ionics 26, 905 (2020) (https://doi.org/10.1007/s11581-019-03259-z). 
[23] Karthik Kannan, D. Radhika, A.S. Nesaraj, Kishor Kumar Sadasivuni, L. Sivarama Krishna, Inorganic Chemistry Communications 122, 108307 (2020). https://doi.org/10.1016/j.inoche.2020.108307.

[24] M. Ibrahim, K. Kannan, H. Parangusan, S. Eldeib, O. Shehata, M. Ismail, R. Zarandah, K.K. Sadasivuni, Coatings 10, 783 (2020) (https://doi.org/10.3390/coatings10080783).

[25] K. Pradeeswari, A. Venkatesan, P. Pandi, K. Karthik, K.V. Hari, Krishna' R. Mohan Kumar, Mater. Res. Express 6(10), 5525 (2019). https://doi.org/10.1088/2053-1591/ab3cae.

[26] J. Theerthagiri, G. Durai, T. Tatarchuk, M. Sumathi, P. Kuppusami, Jiaqian Qin, Myong Yong Choi, Ionics 26(4), 2051 (2020) (https://doi.org/10.1007/s11581-019-03330-9).

[27] T. Rajesh Kumar, P. Prabukanthan, G. Harichandran, J. Theerthagiri, T. Tatarchuk, T Maiyalagan, Gilberto Maia, M. Bououdina, Journal of Solid State Electrochemistry 22(4),1197 (2018) (https://doi.org/10.1007/s10008-017-3865-z).

[28] T. Rajesh Kumar, P. Prabukanthan, G. Harichandran, J. Theerthagiri, A. Meera Moydeen, G. Durai, P. Kuppusami, T. Tatarchuk, Journal of Materials Science: Materials in Electronics 29(7), 5638 (2018). https://doi.org/10.1007/s10854-018-8533-2.

\title{
Р. Наміза ${ }^{1}$, К. Каннан ${ }^{2}$, Д. Радхіка ${ }^{1}$, Г. Крішнамуртзі ${ }^{3}$
}

\section{Сольвотермічне / гідротермальне виробництво вуглецевих нанотрубок для зберігання водню: порівняльне дослідження}

\author{
${ }^{1}$ Університет Джайн, Джакасандра, округ Рамнагара, Iндія, namitha19kkp@gmail.com; radhikadv8@gmail.com \\ ${ }^{2}$ Університет Kamapy, Доха, Kamap, karthikkannanphotochem@gmail.com \\ ${ }^{3}$ Університет Бангалору, Бангалор, Iндія, krisnamurthyg0@gmail.com
}

\begin{abstract}
Наведено результати дослідження щодо виготовлення багатостінних вуглецевих нанотрубок (MWNTs) за допомогою сольвотермічної та гідротермальної процедур, а також електрохімічна поведінка таких наноструктурованих електродних матеріалів для зберігання водню. Фізичні та морфологічні властивості підготовлених вуглецевих нанотрубок вивчали за допомогою рентгенівської дифракції (XRD), скануючої та трансмісійної електронної мікроскопії (SEM та TEM). Крім того, електрохімічні властивості MWCNT виявляли за допомогою гальваностатичного розряду та вимірювання циклічної вольтамперометрії. Результати показали, що обидва типи MWNT демонстрували високу електрохімічну ємність та стабільну циклічність. Цікаво, що MWNT, синтезовані методом гідротермальної процедури, демонструють надзвичайну ємність розряду 423 мАг/г, що стосується накопичення водню 1,5мас.\%, А MWNT, синтезовані сольвотермальною процедурою, показують розрядну ємність $394,8 \mathrm{mAh} / \mathrm{g}$, яка відповідає 1,4 мас.\% і досягнута відтворюваним при $25^{\circ} \mathrm{C}$ приблизно для 100 мг MWCNT. Цей результат свідчить про те, що MWNT роблять електрохімічні матеріали чудовими щодо зберігання водню
\end{abstract} для паливних елементів РЕМ та акумуляторних батарей.

Ключові слова: сольвотермічний / гідротермальний методи; вуглецеві нанотрубки; зберігання водню; перезарядні батареї; електрохімічний метод. 